\title{
Correction to: Methanol extract of Spathodea campanulata P. (Beauv.) leaves demonstrate sedative and anxiolytic like actions on swiss albino mice
}

Anawara Begum ${ }^{1 *}$, Purobee Biswas ${ }^{2}$ and Md. Shahed-Al-Mahmud ${ }^{1,3}$

\section{Correction to: Clin Phytosci 6, 41 (2020) \\ https://doi.org/10.1186/s40816-020-00182-z}

Following publication of the original article [1], the authors identified an error in the author name of Md. Shahed-Al-Mahmud.

The incorrect author name is: Shahed Al-Mahmud

The correct author name is: Md. Shahed-Al-Mahmud

The author group has been updated above.

\footnotetext{
Author details

'Department of Pharmacy, Stamford University Bangladesh, 51, Siddeswari Road, Dhaka 1217, Bangladesh. ${ }^{2}$ Department of Pharmacy, State University of Bangladesh, 77, Satmasjid Road Dhanmondi, Dhaka 1205, Bangladesh. ${ }^{3}$ Department of Microbiology and Immunology, School of Medicine, Tzu Chi University, No. 701, Sec. 3, Zhongyang Rd, Hualien 97004, Taiwan.
}

Published online: 28 June 2020

\section{Reference}

1. Begum, et al. Methanol extract of Spathodea campanulata P. (Beauv.) leaves demonstrate sedative and anxiolytic like actions on swiss albino mice. Clin Phytosci. 2020;6:41 https://doi.org/10.1186/s40816-020-00182-z.

* Correspondence: anawara@stamforduniversity.edu.bd;

anawaraanna@gmail.com

The original article can be found online at https://doi.org/10.1186/s40816-

020-00182-z

1Department of Pharmacy, Stamford University Bangladesh, 51, Siddeswari

Road, Dhaka 1217, Bangladesh

Full list of author information is available at the end of the article

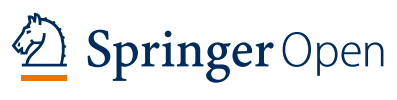

(c) The Author(s). 2020 Open Access This article is licensed under a Creative Commons Attribution 4.0 International License which permits use, sharing, adaptation, distribution and reproduction in any medium or format, as long as you give appropriate credit to the original author(s) and the source, provide a link to the Creative Commons licence, and indicate if changes were made. The images or other third party material in this article are included in the article's Creative Commons licence, unless indicated otherwise in a credit line to the material. If material is not included in the article's Creative Commons licence and your intended use is not permitted by statutory regulation or exceeds the permitted use, you will need to obtain permission directly from the copyright holder. To view a copy of this licence, visit http://creativecommons.org/licenses/by/4.0/. 